This is an electronic reprint of the original article. This reprint may differ from the original in pagination and typographic detail.

Author(s): Lähdesmäki, Tuuli

Title: $\quad$ Politics of tangibility, intangibility, and place in the making of a European cultural heritage in EU heritage policy

Year: $\quad 2016$

Version:

Please cite the original version:

Lähdesmäki, T. (2016). Politics of tangibility, intangibility, and place in the making of a European cultural heritage in EU heritage policy. International Journal of Heritage Studies, 22(10), 766-780. https://doi.org/10.1080/13527258.2016.1212386

All material supplied via JYX is protected by copyright and other intellectual property rights, and duplication or sale of all or part of any of the repository collections is not permitted, except that material may be duplicated by you for your research use or educational purposes in electronic or print form. You must obtain permission for any other use. Electronic or print copies may not be offered, whether for sale or otherwise to anyone who is not an authorised user. 


\title{
Politics of Tangibility, Intangibility, and Place in the Making of a European Cultural Heritage in EU Heritage Policy
}

Tuuli Lähdesmäki

Department of Art and Culture Studies, University of Jyväskylä, Finland

\begin{abstract}
The EU has recently launched several initiatives that aim to foster the idea of a common European cultural heritage. The notion of a European cultural heritage in EU policy discourse is extremely abstract, referring to various ideas and values detached from physical locations or places. Nevertheless the EU initiatives put the abstract policy discourse into practice and concretize its notions about a European cultural heritage. A common strategy in this practice is 'placing heritage' - affixing the idea of a European cultural heritage to certain places in order to turn them into specific European heritage sites. The materialization of a European cultural heritage and the production of physical European heritage sites are crucial elements in the policy through which the EU seeks to govern both the actors and the meanings of heritage. On the basis of a qualitative content analysis of diverse policy documents and informational and promotional material, this article presents five strategies of 'placing heritage' used in the EU initiatives. In addition, the article presents a theoretical model of circulation of the tangible and intangible dimensions of heritage in the EU heritage policy discourse and discusses the EU's political intents included in the practices of 'placing heritage'.
\end{abstract}

Keywords: European cultural heritage, European Union, place, tangible heritage, intangible heritage, politics.

\section{Introduction: EU's Increased Interest in a Cultural Heritage}

During the past fifteen years, the EU has launched several initiatives that particularly seek to produce and promote the idea of a common European cultural heritage that fosters a shared European identity, collective memory, and interpretations of the past. This aim is, however, extremely problematic. What could be perceived as a common European cultural heritage in a Europe that has always included numerous cultural entities? How it is possible to identify a 
common cultural heritage in Europe where narrations of history, interpretations of past events in Europe, and notions about Europe itself differ greatly? Indeed, several surveys among Europeans have indicated that the definitions of national and European heritage vary considerably from one country to another (EC 2007; IPSOS 2007). Despite the constant affirmation of a common European heritage, the notions of it lack conceptual integrity and vary with the location and the occasion (Nic Craith 2012, 19).

The EU's interest in a cultural heritage is in line with its broader political frameworks and discourses. The Maastricht Treaty (effective since 1993) included the first treaty article that explicitly focused on culture, and aimed at 'bringing the common cultural heritage to the fore' (EC 1992, 24). However, not until the end of the millennium did discussions about, and references to, the ideas of a common European heritage become more frequent in EU policy discourse. In the 2000s the idea of a common heritage was brought out in several EU resolutions, agendas, and work plans for culture and was explicitly linked to the European integration process. For example, the European Agenda for Culture claims at its very beginning that the Council of the European Union is 'convinced that culture and its specificity, including multilingualism are key elements of the European integration process based on common values and a common heritage' (CoEU 2007, 1).

The strengthening of the cultural political objectives of the EU has been discussed much in academia (Shore 2000; Sassatelli 2006; O'Callaghan 2011; Näss 2010). Several scholars (Karlsson 2010; Jarausch 2010) have identified the EU's increased interest in culture and the various policies and practices created to promote and govern it as the 'third wave' of the European integration process, brought out after the more or less realized waves of economic and political unification-that are, however, in the current European reality of severe economic, political, and social crises more threatened than ever. The quest for a common heritage, history, and cultural roots aims not just at inspiring a more profound understanding of the European dimension of the past, but it also seeks to legitimate further integration of the EU and its use of power for attaining its aims (Jarausch 2010, 310). Indeed, the EU's attempts for presenting the EU as a 'humanistic enterprise' based on shared cultural features, values, heritage, memory, and history can be perceived as having functional utility, as Shore (1993, 785-6) states. This kind of cultural emphasis aims to appeal to people's feelings of belonging, sense of communality, and cultural and social attachments, thereby striving to justify the promotion of 
EU's identity and integration politics and policies (Lähdesmäki 2014a, 2014b, 2016; Patel 2013; Sassatelli 2009).

Sites, objects, and intangible phenomena 'become' heritage and gain their shared and common meanings in an interactive and continuous process within a specific social context (Delanty 2009; Breglia 2006). Thus, the idea of heritage can be perceived as a form of performance produced and maintained by diverse actors (Smith 2006). When heritage is understood as a continuous process and performance (as is the case in this article), the question of power can be perceived as determining the process of 'becoming' a heritage. Indeed, the power is not only a central matter within the realm of heritage but generative to it (Silva and Mota Santos 2012). The construction of a European cultural heritage is the EU's political project and a form of using discursive, narrative, and performative power (Lähdesmäki 2014a).

The idea of a common heritage primarily has an abstract, ideational meaning. In EU policy discourse, the idea of a common heritage explicitly and implicitly includes various positive, affirmative, and uplifting features and is thus perceived as 'a major asset for Europe and an important component of the European project' (CoEU 2014, 36) to be utilized for promoting the EU's various political, social, cultural, educational and economic goals. The policy discourse aims to strengthen 'European citizens' sense of belonging to the European Union' on the basis of 'shared values and elements of European history' (EC 2011a, 2-3) and to promote 'EU citizenship by preserving and facilitating access to historical sites of shared European memory' (EP 2012, 154).

The interpretations of cultural heritage are commonly fixed to real or imagined places and territories which have real or imagined spatial borders (Ashworth 1994). Spatial interest has particularly impacted the discussions of the national meanings of cultural heritage: during the past decades, various scholars (for example, Hobsbawm 1983; Mitchell 2001; Peckham 2003; Risse 2003; Ashworth, Graham, and Tunbridge 2005) have explained how the idea of a national culture, memory, and history - and of a nation itself - has been constructed through various processes of heritagization. In addition, spatial interest has been broadly applied to studies of heritage production at the local, regional, and global levels and to examinations of encountering the local and global dimensions of cultural heritage (Ashworth, Graham, and Tunbridge 2007; Lowenthal 1998). Although several studies discuss heritage and the heritagization processes at the European level (for example, Ashworth and Larkham 1994; Kaschuba 2008, Nic Craith 
2012; MacDonald 2013), studies have focused less on EU heritage politics. Indeed, the EU's heritage policy has remained a largely unexplored topic in EU, European, and heritage studies. The EU is one of the recent heritage actors in the supranational field of heritage that is actively operating at the European level and attempting to affix the idea of cultural heritage to a continent.

In EU policy discourse a European cultural heritage is commonly discussed in an abstract manner referring to diverse ideas, values, political principles, and unspecified elements of history (Lähdesmäki, forthcoming). The abstract character of a common European cultural heritage in EU policy discourse is, however, concretized when the policies are put into practice. The EU initiatives seek to make a European cultural heritage concrete by fixing its abstract and intangible meanings to material objects and physical sites. In this article, this process of materialization of heritage in a particular site is called 'placing heritage'. The concept refers to the practices of producing physical sites to which a common heritage is considered anchored (Lähdesmäki 2014a).

As the EU is increasingly utilizing the idea of a common cultural heritage in its policy discourse, further critical analysis of the dimensions of heritagization processes in the EU's 'European project' is needed. Although the few previous studies on EU heritage policy have explained the notions of heritage in EU policy discourse (Lähdesmäki, forthcoming) and the political discourses and ideologies manifested in the key EU heritage initiatives (Lähdesmäki 2014a), research on EU heritage policy still lacks a deeper analysis of the interplay between the tangible and intangible dimensions of heritage and its impact on the politics of heritage production. In this article I ask how and why the idea of a European cultural heritage is produced in EU heritage policy discourse through the discursive interplay between and circulation of the tangible and intangible dimensions of heritage and what kind of politics is included in the EU's attempts at 'placing heritage'. The aim of this article is to theorize the process of producing a common European cultural heritage in EU heritage policy discourse by identifying strategies through which abstract ideas and values are turned into tangible sites and objects in order to serve the political purposes of EU heritage politics. Furthermore, the article seeks to demonstrate how the ideas of tangible and intangible heritage are extremely fluid categories in EU heritage policy and how the meanings of heritage move in it between these two conceptual poles: intangible ideas and values are made tangible in the EU's heritage policy discourse, and tangible heritage objects and sites are simultaneously interpreted as manifesting and 
transmitting intangible heritage. The article seeks to explain the logic of circulation of the tangibility and intangibility of heritage in the EU's heritage policy discourse.

The point of view of this interdisciplinary study combines approaches and theories from heritage studies, cultural studies, EU studies, European studies, and cultural policy research. The article proceeds from a conceptual discussion on materiality, place-relation, and the tangibility and intangibility of heritage to a presentation of case initiatives, empirical data, and methods. As a result of the analysis, the article presents five strategies of 'placing heritage' and puts forth a theoretical model of circulation of the tangible and intangible dimensions of heritage in the EU's heritage policy discourse. The article ends with a discussion on the EU's political intents included in the practices of 'placing heritage' and draws final conclusions about the study.

\section{Materiality and Place-Relation of Cultural Heritage}

Cultural heritage is an ambiguous and fluid concept. During the past century, its meanings have transformed from the idea of goods inherited from forefathers to the sense of cultural roots, identity, and belonging (cf. Lowenthal 1998, 4). In the last decades of the twentieth century, the concept faced a semantic change in international heritage policy discourse: the idea of cultural heritage was no longer defined only on the basis of its material aspects, but both tangible objects and intangible phenomena were recognized as heritage (Vecco 2010). However, not until the late 1990s was intangible heritage given broader recognition in international heritage policy discourses. Along with the semantic change, the temporal and social axes of heritagization moved closer together. As Bendix (2009) notes, whereas in the nineteenth and early twentieth centuries only historical sites referring to a distant past were seen as heritage, today contemporary phenomena and intangible cultural heritage, such as different kinds of public festivities and carnivals, can be seen as worthy of heritage recognition; and whereas past heritage practice focused on elite structures, recently heritage practices of the working class and ethnic minorities have also officially been recognized as heritage (Ashworth, Graham, and Tunbridge 2007; Smith et al. 2011). However, the majority of officially labeled heritage still represents the culture of the elite. 
The reconceptualization and the semantic extension have not made the concept of cultural heritage any less ambiguous or fluid. The complex and interdependent relationship between the intangible and tangible forms of cultural heritage has been much discussed in recent scholarly studies (for example, Ahmad 2006; Malpas 2008, Giaccardi and Palen 2008; Smith and Akagawa 2009; Pocock, Collett, and Baulch 2015). Indeed, several studies (for example, Dicks 2000; Smith 2006; Munjeri 2004; Kirshenblatt-Gimblett 2004; Smith and Akagawa 2009) have emphasized how in an epistemological sense the tangible and intangible dimensions of heritage are inevitably intertwined, just as heritage in itself is a constant process of meaning-making and cultural production - a process that Kirshenblatt-Gimblett (2004) defines as a 'metacultural' operation.

Indeed, tangible objects turn into heritage only when socially shared meanings and values are attached to them. Similarly, intangible traditions and values are commonly materialized in processes in which they are framed and fostered as heritage: attempts to transmit and save an intangible heritage for future generations commonly produce diverse concrete records or generate events involving materializing practices.

While the epistemological demarcation between tangible and intangible seems to be difficult to draw, the demarcation is, however, put forward by heritage politics, management, and industries. As Kuutma $(2012,24)$ states, the polarization into tangible and intangible heritage is mainly organizational and political and serves first and foremost the needs of heritage industries and their institutional distinctions. The demarcation between tangible and intangible heritage has its foundation particularly in UNESCO's Convention Concerning the Protection of the World Cultural and Natural Heritage (1972) and Convention for the Safeguarding of the Intangible Cultural Heritage (2003). In the first convention, the definition of cultural heritage focuses on tangible heritage: 'monuments', 'groups of buildings', and 'sites' (UNESCO 1972, 2). To broaden the scope of safeguarding heritage (and as response to intense lobbying by Asian and African countries), the second convention focuses on intangible cultural heritage, which is defined as 'the practices, representations, expressions, knowledge, skills - as well as the instruments, objects, artefacts, and cultural spaces associated therewith-that communities, groups and, in some cases, individuals recognize as part of their cultural heritage' (UNESCO $2003,2)$. In the conventions, the idea of tangibility refers to the material, touchable dimension of heritage, while the idea of intangibility accents its immaterial, non-touchable dimension. Instead of approaching these concepts as two separate categories, the article emphasizes their complex interplay, as argued for example by Munjeri (2004), Kirshenblatt-Gimblett (2004), and 
Smith (2006), but it also recognizes their divergent semantics in current heritage policy discourse.

The idea of the tangibility of heritage is intertwined with the Western conception of identity. The linkage between a durable tangible heritage and the continuity of people across generations is a widespread implicit — and often also explicit — conception in the Western world, especially in Europe, as Macdonald $(2006,11)$ claims. In this conception, material culture as heritage is understood not simply as representing and transmitting an identity but also as materializing and objectifying it: 'a physical heritage acts as the material substance of identity' (Macdonald 2006, 11). Macdonald's (2013) study on practices of remembrance in Europe - or European "memorylands", as she calls them-emphasizes how the ambition to materialize remembering is about the materialization of identity. Although heritage materializes identities and enables identification(s) within communities, a material cultural heritage as such does not have any innate meanings (Smith and Akagawa 2009). As Macdonald (2006, 11) notes, a material cultural heritage is 'primarily a discourse and a set of practices concerned with the continuity, persistence, and substantiality of collective [--] identity'.

The relationship between the intangible and tangible forms of cultural heritage can be perceived as a 'situated relationship' and 'always in place', as Giaccardi and Palen claim $(2008,283)$. Similarly, Malpas $(2008,199)$ emphasizes how heritage is always configured in relation to the material — to 'particular places, pathways, and things'. Indeed, heritage — whether defined as tangible or intangible - is not isolated from the physical settings where history is interpreted as having occurred-and where heritage is interpreted as occurring today. A place makes a heritage tangible: intangible meanings are materialized in and to a particular site through diverse discursive, narrative, and performative acts (cf. Pocock, Collett, and Baulch 2015; Kaufman 2013; Macdonals 2013). Smith (2006) has emphasized how heritage is in fact entirely performative, but certain places and artifacts bring to this performance a sense of occasion and materiality.

The relationship between heritage and place has been a common topic in heritage studies. Interpretations of heritage and its communal meanings have often been perceived as territorial and place-bound (for example, Ashworth 1994; Graham, Ashworth, and Tunbridge 2000; Ashworth, Graham, and Tunbridge 2007) and, thus, the concept of heritage has been defined as an inherently spatial phenomenon. 'All heritage occurs somewhere', as Graham, Ashworth, and 
Tunbridge $(2000,4)$ note. In anthropologically and ethnologically orientated heritage studies, the place-relation of heritage and the connection between heritage and identities have often been explored by emphasizing how people (seek to) belong to a place by processing heritage. In addition, various studies by human geographers have emphasized the spatial meanings of heritage created in diverse heritage practices and discourses. However, Harvey (2014) has argued that many of the studies on the place-relation of heritage are excessively place-bound, ignoring the relational nature of spatial borders and the fluidity of ideas related to territorial entities. He emphasizes that the conception of heritage needs to be tied to 'a progressive (and relational) sense of place, that is place as a temporary constellation of connectivity' (Harvey 2014, 589). The role of place in heritage production, particularly in that of bodies in power, needs to be perceived as a relational and temporary constellation and in reference to a larger social, political, and economic set of relationships. Naming and labeling European cultural heritage in the EU heritage initiatives is an act of articulation of linkages of what 'Europe' might be or is wished to be in a particular place. In addition, the initiatives are an act of materializing these linkages through diverse concrete practices of 'placing heritage'.

\section{Cases, Data, and Methods}

The empirical analysis of this article focuses on six EU initiatives that explicitly seek to foster a cultural heritage in Europe. The European Commission's web site lists three of the Commission's EU actions as specifically dedicated to cultural heritage. These are: the European Heritage Days, the EU Prize for Cultural Heritage, and the European Heritage Label. The European Heritage Days were officially launched by the Council of Europe in 1991, but since 1999 they have been organized as a joint initiative between the Council of Europe and the EU. Every September this locally-led initiative opens buildings with restricted access together with museums, monuments, and heritage sites for free entry to the public in the 50 signatory states of the European Cultural Convention. In 2002, the European Commission launched the European Union Prize for Cultural Heritage as a part of the implementation of the Culture 2000 program. Europa Nostra, the pan-European federation for cultural heritage with representatives from over 200 heritage NGOs active throughout Europe, was selected to run the prize scheme. The prizes are annually awarded in four categories: conservation; research; dedicated service by individuals or organizations; and education, training, and awareness-raising. Europe Nostra 
has explicitly announced its support for the EU's interests in strengthening the EU-led governance of cultural heritage in Europe (Europea Nostra 2005, 5).

The Commission's most recent heritage action is the European Heritage Label. Its scheme was launched in 2006 as an intergovernmental European initiative and by 2011, 67 sites were awarded with the label. The initiative was considered difficult to effectively implement on an intergovernmental basis due to the lack of common coordination and possibilities for operational arrangements (Lähdesmäki 2014a). The scheme was, however, considered important by the European Parliament and the Council of the European Union, and in 2008 the Council adopted conclusions transforming the initiative into an official EU action. Previously awarded sites were required to reapply for the label. The labeled sites are first pre-selected at the national level, the final selection is made by an expert panel appointed at the EU level, and the labels are awarded by the European Commission. So far, 29 sites have been awarded with the renewed label. Altogether $24 \mathrm{EU}$ member states have announced their participation in the initiative.

The European Heritage Label was created by using the longest-running and perhaps most influential EU cultural initiative, the European Capital of Culture, as its case in point. The European Capital of Culture was launched in 1985 as an intergovernmental initiative and turned into an official EU action in 1999. As in the case of the European Heritage Label, the European Commission annually designates cities as European Capitals of Culture on the basis of their applications. The candidate cities first compete for the designation between national candidates among which national panels suggest the final candidates to an expert panel appointed at the European level. In both initiatives the selection criteria emphasize the importance of 'highlighting the common aspects of European cultures, heritage, and history, as well as European integration and current European themes' (EC 2014a, 5). Although the European Capital of Culture has a broader cultural and urban focus than the European Heritage Label, the initiative nevertheless includes strong emphasis on promoting cultural heritage (Lähdesmäki 2012a, 2014c, 63-64). Thus, in EU policy reports it has been listed as the fourth EU action relevant to the heritage sector (see EC 2014b, 7-8).

The European Parliament runs two cultural projects promoting a European cultural heritage: Parlamentarium, the European Parliament's visitor center opened in the administrative block of the Parliament in 2011, and the House of European History, a new museum to be opened in 
Brussels in 2016 with a focus on Europe's twentieth century and the history of European integration. Parlamentarium is spread over three floors and includes over 3000 square meters of exhibition space divided into two thematic sections: 'History area' and 'United in Diversity'. The exhibition narrative in Parlamentarium emphasizes and repeats the selected 'key events' of twentieth century Europe, such as the World Wars, setting up the Council of Europe and the European Community / Union, the collapse of Communist regimes, and the signing of various agreements that have strengthened cooperation and integration in Europe (Lähdesmäki 2016).

The heritage discourse in the EU documents related to these initiatives is surprisingly consistent, although the discourse is formed as a product of various negotiations and compromises. Indeed, the EU does not form a single actor in the political sphere or a unanimous author of the European narrative and identity (Sassatelli 2006, 20). Its decisions and policies are made through negotiations between various EU bodies and actors. In the preparation of the above-mentioned initiatives, the key political actors of the EU have been: the European Commission; the European Parliament; the Council of the European Union; and the Committee of the Regions. In addition, various experts or groups of experts appointed by the Commission or the Parliament have participated in the preparation of the initiatives. While the preparation phase of these initiatives included active negotiation on various practical issues related to their implementation (for example, how a particular initiative should be coordinated, monitored, or funded), the idea of a common European heritage or the aim of fostering it through specific EU heritage initiatives did not raise debate or disagreement - at least not such that would have been recorded in the policy documents. In fact, the EU heritage discourse seems to be quite unanimous. Particularly after the decisions on the initiatives have been made, the communication about them, for example, in the promotional and informational material of the Commission and the Parliament, is extremely coherent and 'univocal'.

The data of this study consist of EU policy documents and official informational and promotional material produced or commissioned by the EU bodies during the preparation, launch, and/or evaluation phases of these initiatives. The aim of the data selection was to collect all official policy and promotional documents with a focus on six case initiatives. The 57 documents included in the data consist of: handbooks/guides (14), preparatory documents (9), leaflets (6), application documents (6), official reports (6), general communication documents by the EU bodies (5), official decisions of the European Parliament and the Council of the European Union (4), press releases (4), position papers (2), and a communication document 
from the European Commission (1). The length of the documents ranges from one to 94 pages, and they have been produced between the years 1999 and 2015. In addition, the data include texts on the web sites of the six initiatives under the official web site of the European Commission or the Parliament. The data were gathered from EUR-Lex, a database of legal texts of the European Union, and from the official web sites of the European Commission and the Parliament.

The data were analyzed using qualitative content analysis (Tesch 1990; Miles and Huberman 1994), mixing both 'conventional' and 'directed' orientations of the method (Hickey and Kipping 1996; Hsieh and Shannon 2005). In the analysis, the data were coded with thematic keywords derived from the data. In addition to this text-based starting point of the 'conventional' content analysis and its inductive coding logic (Boyatzis 1998), the conceptual framework of tangible and intangible heritage as introduced, for example by UNESCO, was utilized in the study as a coding guide. In this 'directed' orientation of the method the ideas of tangibility and intangibility were used as codes to perceive how EU heritage policy discourse emphasizes both the distinctiveness and interwoven nature of the tangible and intangible dimensions of heritage. This approach made it possible to recognize how the idea of heritage in the data is situationally related to material and physical objects and sites, following the ethos of UNESCO's 1972 Convention and its policy discourse on heritage, but is also affixed to diverse social and societal ideas, values, and political principles, following the semantics of UNESCO's 2003 Convention. The analysis not only centered on simply recognizing the concepts of 'tangible heritage' or 'intangible heritage' from the data: it focused more deeply on exploring the articulation of a European cultural heritage in relation to materiality and place. In the data the concepts of 'tangible heritage' and 'intangible heritage' as such were rarely used. Even though these concepts were rarely used, the idea of heritage was, however, commonly given meanings and made sense through the semantics related to these concepts in the international heritage policy discourse, such as in the policy discourse of UNESCO.

First the analysis focused on recognizing strategies through which the idea of a European cultural heritage is intended to be concretized, materialized and placed in a physical setting in the selected initiatives. Secondly, the analysis sought to perceive the interplay between the tangible and intangible dimensions of heritage in EU policy discourse. After several re-readings of the data, the observations from the data were arrange into clusters that function as the basis for the strategies of 'placing heritage' and the phases in the model of the circulation of the 
tangible and intangible dimensions of heritage discussed in the next section. The clusters of the first phase of the analysis were entitled: rewarding labels and awards to sites; particularizing cities; emphasizing historical monuments; creating new museums or exhibition spaces; and iconizing EU administrative buildings. The clusters in the second phase of the analysis were entitled: practices and discourses of tangiblizing heritage; practices and discourses of placing heritage; practices and discourses of localizing heritage, practices and discourses of Europeanizing heritage; and practices and discourses of intangiblizing heritage. Finally, the analysis sought to identify political intents included in the practices of 'placing heritage' in the initiatives. The following sections include several quotations selected from the clusters to demonstrate the results of the analysis and the theoretical argumentation on the circulation of tangibility and intangibility of heritage and the politics included in it in EU heritage policy discourse.

\section{Politics of Tangibility and Intangibility in the EU Initiatives}

Vos (2011) claims that the idea of a European cultural heritage is intentionally vaguely outlined in the EU's policy discourse since explicit pronouncements on what makes a heritage 'European' might lead to conflicts and problems regarding the ownership of the heritage and its national interpretations. In the EU's policy discourse, the idea of a common heritage is commonly discussed in relation to a group of abstract ideas and values, which Europeans are expected to share and which are assumed to function as a common basis for shared memories and identity in Europe. For example, candidates applying for the European Heritage Label are expected to demonstrate "their place and role in the development and promotion of the common values that underpin European integration' (EC 2011a). The establishment of the European Heritage Label is justified in the policy rhetoric as follows:

For citizens to give their full support to European integration, greater emphasis should be placed on their common values, history and culture as key elements of their membership of a society founded on the principles of freedom, democracy, respect for human rights, cultural and linguistic diversity, tolerance and solidarity. (EC 2011a, 1) 
The idea of a European cultural heritage stems in the EU's heritage policy discourse from general societal ideas, values, and political principles, such as above-mentioned freedom, democracy, respect for human rights, cultural and linguistic diversity, tolerance and solidarity, repeated in the policy documents. These ideas, values, and principles are perceived as being manifested in a European cultural heritage, but also as being a kind of (intangible) heritage themselves (Lähdesmäki, forthcoming).

\section{Strategies of 'Placing Heritage'}

Although abstract ideas and values can be easily utilized as political tools, their vagueness, however, decreases their potential as tools of governance. Thus, the EU heritage policy seeks to make the idea of a European cultural heritage more concrete. The EU heritage initiatives materialize, concretize, and affix the abstract idea of a common European cultural heritage to places in diverse ways. The EU's most evident strategy of 'placing heritage' is rewarding labels and awards to sites. Labels and awards, such as the European Heritage Label and the EU Prize for Cultural Heritage, mark physical places as significant European cultural heritage sites. They do it not only by narrating the meanings of the sites as having a European significance in diverse informational and promotional material, but also by marking the sites with official plaques, flags, and logos of the awards. Involvement in the EU's heritage initiatives obligates the heritage actors of the sites to make their involvement visible in situ and in their promotional and marketing material. Although the awarded and labeled sites may foster intangible phenomena as a European cultural heritage, the EU heritage policy expects these phenomena to be placed in a particular site. As the guide for European Heritage Label candidates emphasizes, '[i]n the case of cultural goods and objects, as well as intangible heritage, there must be a link to a clearly identifiable physical space in which the information and educational activities will be carried out' (EC 2011b, 5).

In addition to awarding particular sites, the EU initiatives present whole cities and towns and their history as heritage. In the strategy of particularizing cities, the act of 'placing heritage' is implemented on a broader scale: the history of a whole city or town is interpreted as having a European dimension. Particularizing cities as a European cultural heritage occurs particularly in the implementation of the European Capital of Culture program (Lähdesmäki 2011, 2012a), 
but the European Heritage Label has also been awarded to cities, towns, or their certain districts. $^{1}$

One of the common strategies of 'placing heritage' in the EU initiatives is emphasizing historical monuments. This strategy affixes the European dimension of heritage to historical buildings and monuments that are interpreted as stages for important events in common European history and/or as manifesting shared European ideas and values. These kinds of buildings are recognized particularly with the European Heritage Label, but built environments, architecture, and historical monuments are also the focus in the European Heritage Days and the EU Prize for Cultural Heritage, particularly in the category of 'conservation'. In this strategy, the European dimension of heritage is also commonly fixed to diverse architectural and artistic styles and movements which have been canonized as European in Western art and cultural history writing. For example, candidate cities applying for the title of European Capital of Culture have been advised 'to highlight artistic movements and styles shared by Europeans which it has inspired or to which it has made a significant contribution' and 'to exploit the historic heritage, urban architecture, and quality of life in the city' (EC 1999, 5) in their cultural program. Similarly, candidates applying for the European Heritage Label are expected to demonstrate 'their place and role in European history and European integration, and their links with key European events, personalities, or movements' (EC 2011a, 3). Art historical styles and architecture illustrate the idea of a European cultural heritage in Euro banknotes, as well.

Creating new museums or exhibition spaces concretizes and places European cultural heritage into particular touristic and educational buildings. This strategy is utilized in several sites awarded the European Heritage Label: the awarded heritage has been or is planned to be made accessible by creating various kinds of exhibition spaces at the site. In addition, the European Parliament has established two public sites, Parlamentarium and the House of European History, for displaying the common historical and cultural foundations of EU Europe. Their location and exhibition narratives intertwine the idea of a cultural heritage and the political heritage of the EU. The establishment of Parlamentarium and the House of European History is justified in the EU's heritage policy discourse by emphasizing the need for a public space in which the story of EU Europe can be told and the memory of the shared past can be fostered. Transmitting heritage and its 'message' is perceived to need a concrete place consecrated for this function. As the president of the European Parliament, Hans-Gert Pöttering, stated when initiating the House of European History: 
I should like to create a locus for history and for the future where the concept of the European idea can continue to grow. [--] It should [be] a place where a memory of European history and the work of European unification is jointly cultivated, and which at the same time is available as a locus for the European identity to go on being shaped by present and future citizens of the European Union. (Committee of Experts 2008, 4.)

As the quotation indicates, heritage, history, memory, place, and identity form in the policy discourse a tight combination — a 'memory complex' in Macdonald's (2013) terms.

In telling the story of EU Europe, Parlamentarium and the House of European History bring/will bring to the fore history and functions of the administrative bodies of the EU. These bodies are easily concretized by presenting them through their iconic venues. In addition, the European Heritage Label was awarded to the European District of Strasbourg in 2016. The report of the expert panel emphasizes 'a strong European character' in the EU administrative buildings in the European District of Strasbourg:

As the idea of a united Europe gradually took hold, more and more buildings were built for European institutions in this district, for example, the Palace of Europe, the Agora building housing the Council of Europe's administration, the European Court of Human Rights, the European Parliament of the European Union, as well as other institutions with a strong European character. [--] Bilingual Strasbourg has a symbolic location in the centre of Europe. After the Second World War, European institutions created for maintaining peace were housed in an area which became the European district Strasbourg. These institutions are the drivers of European consolidation; they are central to the strengthening of human rights and to the defence of democratic values and the rule of law. The district is also host to many events relating to Europe which underscore the candidate site's European dimension. (EC 2015, 14.)

The strategy of iconizing EU administrative buildings 'places heritage' by turning the venues of the European Parliament, the European Commission, the Council of Europe, and other institutional seats in Brussels, Strasbourg, and Luxembourg into landmarks and architectural 
symbols of EU Europe and its political heritage. Guided tours for visitors in the administrative buildings strengthen their iconic role and culturalize them. In addition, the iconization of EU administrative buildings simultaneously particularizes Brussels, Strasbourg, and Luxembourg as capitals of EU Europe - not only in the administrative sense, but also in the cultural and heritage-related sense.

\section{Circulation of Tangibility and Intangibility in EU Heritage Policy Discourse}

The EU heritage policy and initiatives are processes in which the tangible and intangible dimensions of a European cultural heritage are in constant circulation. The analysis of the data brought to the fore five interdependent phases in this process of circulation; the model in Figure 1 illustrates this process and exemplifies how the categories of 'tangible' and 'intangible' are intertwined with each other in it. It is through this process that the idea of a common European cultural heritage is being produced, given meanings, and justified in EU heritage policy discourse.

[Figure 1 near here]

Firstly in this process, various abstract ideas, values, and political principles detached from material attachments and repeated in policy discourse (such as peace, freedom, democracy, human rights, cultural and linguistic diversity, tolerance, solidarity, transnational co-operation, unity of Europe, etc.) are materialized and made tangible by interpreting diverse objects as their manifestations (cf. Lähdesmäki 2014b, 2012b). For example, the 3 May 1791 Constitution of the Polish-Lithuanian Commonwealth - labeled as European Heritage in 2015-is explained in the report by the expert panel as 'an expression of the liberal political and philosophical ideas of the European Enlightenment, which gave primacy to reason, law, and freedom' and 'a symbol of democratic and peaceful transformation of a political system, which is part of the European ideals' (EC 2014c, 12). In the policy rhetoric, the constitution as an old, original, archived, and tangible object manifests these 'ideas' and 'ideals'.

Secondly, the abstract and intangible dimensions of heritage are commonly materialized in EU heritage policy discourse by 'placing' them; i.e., by affixing ideas, values, and meanings to places and/or creating particular sites for heritage. For example, the idea of peace is made 
tangible through the Peace Palace, the seat of international law in The Hague, which was given the European Heritage Label in 2014. Its 'European significance' is explained in the report by the expert panel as follows:

In European and world collective memory, the city of The Hague has been associated for more than a hundred years not only with the venue of the First World Peace Conference in 1899 and the sphere of peace dialogue, but also with the subsequent peace conventions to which the city gave its name. [--] The Peace Palace is thus an icon and a symbol of Peace and Justice in Europe and in the word, a 'Peace Shrine' stressing at the same time the significance of European efforts for peace processes. (EC 2013, 5.)

In the discourse of the quotation, the idea of peace is affixed to "a Peace Shrine" - an expression that emphasizes the cultural value of the building - by appealing to the history of the site as a 'real' venue of peace-making, but also by describing it as an "icon" and a "symbol" of peace and justice in Europe.

Thirdly, when European cultural heritage is affixed to places, it is commonly interpreted in official informational and promotional material from a local point of view. In these interpretations, European cultural heritage is thus easily localized: heritage sites are contextualized by emphasizing how history perceived as European occurred at the local level. Indeed, heritage products designed to shape or reinforce place-identities tend strongly towards particularization and aim to stress the uniqueness of the specific historical experience and differentiate it from other experiences elsewhere (Ashworth 1994, 25).

The explicit aim of the EU heritage policy is to bring to the fore and foster a common European cultural heritage. Therefore, the policy discourse emphasizes a European dimension of the heritage sites, and thus, fourthly, localized heritage is also simultaneously Europeanized: local historical events, artistic creations, personalities, and movements are narrated in the data as having European significance and meaning (Lähdesmäki 2014a). Fifthly, explicating the European dimension of local historical events 'intangiblizes' heritage, since a common basis for a European cultural heritage is most easily found and created from abstract and generalized values and ideas. For example, the report by the expert panel justifies the European significance 
of the site of the Union of Lublin — awarded with the European Heritage Label in 2015-by explaining it as 'an important milestone in the development of democratic principles' in Europe:

The site of the Union of Lublin (1569), located in the city of Lublin, consists of three historic monuments - the Chapel of the Holy Trinity, the Union of Lublin monument, and the Dominical monastery, which are all linked to the signing of the Union of Lublin in 1569. This event sealed the constitutional union of the Kingdom of Poland and the Grand Duchy of Lithuania, resulting in the creation of a commonwealth republic with a single parliament, an elected king, one currency, and religious and ethnic tolerance. Thus the sites in Lublin stand as physical reminders of a unique entity in European history and an important milestone in the development of democratic principles. (EC 2014c, 9.)

In the discourse of the quotation, a local historical event, physical historical monuments, democratic principles as a value manifested by the buildings, and the European dimension of the site intertwine.

\section{Politics of 'Placing Heritage'}

Why is the EU so fascinated in creating tangible heritage sites? Concretization and materialization of a European cultural heritage has a crucial role in EU heritage politics. Localized collective memories, interpretations of the past, historical narrations, and their concrete - and thus 'real' - manifestations are highly affective matters (Smith 2011; Smith and Campbell 2015). A material heritage appeals to people's feelings of belonging, sense of communality, and cultural and social attachments (Crang and Tolia-Kelly 2010) —and thus it functions as an effective instrument in the EU's ideological and (identity) political attempts. Indeed, historical memory is best served by anchoring collective meanings of the 'common' past in the concrete and visible elements of specific sites (Yeoh and Kong 1997; Macdonald 2013).

The politics of 'placing heritage' has several explicit and implicit goals in the EU's heritage policy discourse. First, physical heritage sites that display historical remnants or architectural or artistic masterpieces and narrate 'crucial' stories from the past are likely to invoke affective 
interest among people. The EU takes advantage of the appeal of heritage and simultaneously uplifts the image of the EU as a cultural rather than a bureaucratic political community (Lähdesmäki 2014a). Secondly, materialized heritage creates concrete building blocks for a European identity project. Through heritage sites a European identity can be constructed as a 'thick' cultural identity instead of a 'thin' political or civic identity (on 'thick' and 'thin' identities see, for example, Delanty 2003; Davidson 2008). Thirdly, 'placing heritage' is closely related to various social motives that seek to strengthen social inclusion and integration by promoting the participation of local people in various heritage activities at the site and by involving them in practices of fostering a common heritage.

Fourthly, 'placing heritage' enables the visibility of the EU at the sites, since the EU expects the sites to promote their status as an EU initiative in their informational and promotional material and to mark the site with the logos, flags, and slogans of the initiatives. By branding heritage, the EU not only influences its public image but also marks the symbolic 'ownership' of the heritage sites. Thus the 'EU heritage sites' indicate the cultural interest - and power-of the EU and the reach of EU governance into the domains of culture, history, and heritage. Fifthly, 'placing heritage' promotes the economic motives of the EU. Heritage is also a commodity created to satisfy contemporary consumption and a product planned to market and sell place-identities (for example, Ashworth 1994). Commodification of heritage needs a place: physical heritage sites can be built up as touristic venues where visitors come to spend their time and money. 'Placing heritage' is an act that can be used to promote tourism, heritage industries, and more general regeneration of the town, city, or region.

\section{Conclusions}

In recent discourse on heritage management and international heritage conventions, cultural heritage is commonly discussed as being split into two conceptual categories: tangible and intangible heritage. In academia, however, this split has been criticized and the categories have been defined and theorized as being interdependent (Smith 2006; Munjeri 2004; KirshenblattGimblett 2004; Smith and Akagawa 2009). This analysis brought to the fore how the tangible and intangible dimensions of cultural heritage are closely intertwined and extremely fluid categories in the EU's heritage policy discourse. Due to their situational, relational, and discursive nature, these dimensions are in constant movement. The study presented a theoretical 
model of circulation of the tangible and intangible dimensions of a European cultural heritage in the EU's heritage policy discourse. This circulation includes the following interdependent phases: interpreting material objects as manifestations of intangible abstractions; affixing abstractions and objects to places and creating particular heritage sites; interpreting and contextualizing places and sites locally; interpreting and narrating the place and its context as having a European significance; and abstracting a European significance.

Naming and labeling a European cultural heritage is a political project of the EU. The EU heritage policy discourse and initiatives not only aim to foster a cultural heritage in Europe, they are instruments with which the EU produces the idea that there is a shared European cultural heritage. The recurring attempt to concretize and materialize a European cultural heritage has a crucial role in EU heritage and identity politics. A common strategy of these politics is 'placing heritage': affixing the idea of a European cultural heritage to certain physical places and locations in order to turn them into particular European heritage sites. This analysis of the EU initiatives revealed five strategies of 'placing heritage': rewarding labels and awards to sites; particularizing cities; emphasizing historical monuments; creating new museums or exhibition spaces; and iconizing EU administrative buildings. Thus EU heritage policy discourse reflects the traditional Western conception of heritage with its emphasis on a placebound, tangible dimension of heritage that is perceived as a crucial element of historical continuity and an important source of a European identity (cf. Macdonald 2006; 2013). Some of the identified strategies, such as monumentalization and musealization of the past, are common from various micro- and macrolevel processes of heritagization, as for example Macdonald's (2013) study on European “memorylands" indicates.

'Placing heritage' is about the power to select, mark, and define the meanings of cultural heritage. It is an act that utilizes the relationality and fluidity of the meanings of places; the unstable, transforming, and negotiated nature of places enables them to be framed with various meanings, such as interpreting them as heritage sites with a particular European significance. The logic of circulation of the tangibility and intangibility of heritage in EU heritage policy discourse and the attempts to concretize and affix the idea of heritage to places in the EU initiatives stems from functional utility of heritage sites for EU policy. 'Placing heritage' is an affective and therefore effective strategy of using power. It is the EU's affective tool for governing both the meanings of a European cultural heritage and heritage actors in Europe. 


\section{Acknowledgements}

This work was supported by the Academy of Finland under Grant SA274295 (EUCHE) and the European Research Council (ERC) under the EU's Horizon 2020 research and innovation program under Grant 636177 (EUROHERIT).

\section{References}

Ahmad, Y. 2006. "The Scope and Definitions of Heritage: From Tangible to Intangible." International Journal of Heritage Studies 12 (3): 292-300.

Ashworth, G. J. 1994. "From History to Heritage - From Heritage to Identity." In Building a new heritage. Tourism, Culture and Identity in the New Europe, edited by G. J. Ashworth and P. J. Larkham,13-30. London: Routledge.

Ashworth, G., B. Graham, and J. Tunbridge. 2005. "The Uses and Abuses of Heritage." In Heritage, Museums and Galleries. An Introductory Reader, edited by G. Corsane, 26-35. London: Routledge.

Ashworth, G, B. Graham, J. Tunbridge. 2007. Pluralising Pasts: Heritage, Identity and Place in Multicultural Societies. London: Pluto Press.

Ashworth, G. J. and P. J. Larkham. eds. 1994. Building a New Heritage. Tourism, Culture and Identity in the New Europe. London: Routledge.

Bendix, R. 2009. "Heritage between Economy and Politics: An Assessment from the Perspective of Cultural Anthropology." In Intangible Heritage, edited by L. Smith and N. Akagawa, 253-269. London, Routledge.

Boyatzis, R. 1998. Transforming Qualitative Information: Thematic Analysis and Code Development. Thousand Oaks: Sage. 
Breglia, L. C. 2006. Monumental Ambivalence. The Politics of Heritage. Austin: University of Texas Press.

CoEU. 2007. Resolution of the Council of 16 November 2007 on a European Agenda for Culture (2007/C 287/01). Official Journal of the European Union C 287: 1-4.

CoEU. 2014. Council conclusions of 21 May 2014 on cultural heritage as a strategic resource for a sustainable Europe. Official Journal of the European Union C 183: 36-38.

Committee of Experts. 2008. Conceptual basis for a House of European History. Brussels: European Parliament.

Crang, M. and D. Tolia-Kelly. 2010 "Nation, Race and Affect: Senses and Sensibilities at National Heritage Sites.” Environment and Planning A 42 (10), 2315-2331.

Davidson, A. C. 2008. “Through Thick and Thin: 'European Identification' for a Justified and Legitimate European Union.” Journal of Contemporary European Research 4 (1): 32-47.

Delanty, G. 2003. "Is There a European Identity?" Global Dialogue 5 (3-4). http://www.worlddialogue.org/content.php?id=269

Delanty, G. 2009. "The European Heritage: History, Memory, and Time." In The Sage Handbook of European Studies, edited by C. Rumford, 36-51. London: Sage.

Dicks, B. 2000. Heritage, Place and Community. Cardiff: University of Wales Press.

EC. 1992. Treaty on European Union (92/C191/01). Official Journal of the European Communities NoC 191: 1-112.

EC. 1999. Decision 1419/1999/EC of the European Parliament and of the Council of 25 May 1999 establishing a Community action for the European Capital of Culture event for the years 2005 to 2019. Official Journal of the European Communities L 166: 1-5. 
EC. 2007. Eurobarometer Survey on Cultural Values within Europe. Luxembourg: European Communities.

EC. 2011a. Decision no 1194/2011/EU of the European Parliament and of the Council of 16 November 2011 establishing a European Union action for the European Heritage Label. Official Journal of the European Union L 303: 1-9.

EC. 2011b. European Heritage Label. Guide for candidate sites. 2011. Brussels: European Commission.

EC. 2013. European Heritage Label. 2013 Panel report. Brussels: European Commission.

EC. 2014a. Decision no 445/2014/EU of the European Parliament and of the Council of 16 April 2014 establishing a Union action for the European Capitals of Culture for the years 2020 to 2033 and repealing Decision No 1622/2006/EC. Official Journal of the European Union L 132: $1-12$.

EC. 2014b. Mapping of cultural heritage actions in European Union policies, programmes and activities. Brussels: European Commission.

EC. 2014c. European Heritage Label. 2014 Panel report. Brussels: European Commission

EC. 2015. European Heritage Label. 2015 Panel report. Brussels: European Commission.

EP. 2012. Parliament's position on the 2011 draft budget as modified by the Council - all sections (P7_TA(2010)0372). Official Journal of the European Union CE 70: 149-161.

Europea Nostra. 2005. Cultural heritage counts for Europe. Position paper of Europa Nostra, the Pan-European Federation for Cultural Heritage. Brussels: Europa Nostra.

Giaccardi, E., and L. Palen. 2008. "The Social Production of Heritage through Cross-Media Interaction: Making Place for Place-Making.” International Journal of Heritage Studies 14 (3): 281-297. 
Graham, B., G. Ashworth, J. Tunbridge. 2000. A Geography of Heritage: Power, Culture and Economy. London: Hodder Arnold Publication.

Harvey, D. 2014. "Heritage and Scale: Settings, Boundaries and Relations." International Journal of Heritage Studies 21 (6): 577-593.

Hickey, G. and C. Kipping. 1996. Issues in Research. A Multi-Stage Approach to the Coding of Data from Open-Ended Questions. Nurse Researcher 4: 81-91.

Hsieh, H-F. and S. E. Shannon. 2005. Three Approaches to Qualitative Content Analysis. Qualitative Health Research 15 (9): 1277-1288.

Hobsbawm, E. 1983. "Introduction: Inventing traditions.” In The Invention of Tradition, edited by E. Hobsbawm and T. Ranger, 1-14. Cambridge: Cambridge University Press.

IPSOS. 2007. Enquête sur les Européens, les patrimoines de l'Europe et le patrimoine européen. Paris: IPSOS / Ministère de la Culture et de la Communication.

Jarausch, K. H. 2010. "Nightmares or Daydreams? A Postscript on the Europeanisation of Memories.” In A European Memory? Contested Histories and Politics of Remembrance, edited by M. Pakier and B. Stråth, 309-320. New York: Berghahn Books.

Karlsson, K-G. 2010. "The Uses of History and the Third Wave of Europeanisation." In A European Memory? Contested Histories and Politics of Remembrance, edited by M. Pakier and B. Stråth, 38-55. New York: Berghahn Books.

Kaschuba, W. 2008. "Cultural Heritage in Europe: Ethnologists' Uses of the Authentic." Anthropological Yearbook of European Cultures 17 (2): 34-46.

Kaufman, N. 2013. "Putting Intangible Heritage in its Place(s): Proposals for Policy and Practice.” International Journal of Intangible Heritage 8: 20-36. 
Kirshenblatt-Gimblett, B. 2004. "Intangible Heritage as Metacultural Production." Museum International $56(1-2): 52-65$.

Kuutma, K. 2012. "Between Arbitration and Engineering: Concepts and Contingencies in the Shaping of Heritage Regimes." In Heritage Regimes and the State, edited by R. F. Bendix, A. Eggert and A. Peselmann, 21-36. Göttingen: Universitätsverlag Göttingen.

Lähdesmäki, T. 2011. "Contested Identity Politics: Analysis of the EU Policy Objectives and the Local Reception of the European Capital of Culture Program.” Baltic Journal of European Studies 1 (2): 134-166.

Lähdesmäki, T. 2012a. "Rhetoric of Unity and Cultural Diversity in the Making of European Cultural Identity.” International Journal of Cultural Policy 18 (1): 59-75.

Lähdesmäki, T. 2012b. "Politics of Cultural Marking in Mini-Europe: Anchoring European Cultural Identity in a Theme Park.” Journal of Contemporary European Studies 20:1, 29-40.

Lähdesmäki, T. 2014a. "The EU's Explicit and Implicit Heritage Politics.” European Societies 16 (3): 401-421.

Lähdesmäki, T. 2014b. "Transnational Heritage in the Making. Strategies for Narrating Cultural Heritage as European in the Intergovernmental Initiative of the European Heritage Label." Ethnologica Europaea 44 (1): 75-93.

Lähdesmäki, T. 2014c. Identity Politics in the European Capital of Culture Initiative. Joensuu: University of Eastern Finland.

Lähdesmäki, T. 2016. "Narrativity and Intertextuality in the Making of a Shared European Memory." Journal of Contemporary European Studies, 1-16. DOI:10.1080/14782804.2016.1159544.

Lähdesmäki, T. (accepted, forthcoming) "Comparing Notions on European Cultural Heritage in EU Policy Discourse and Scholarly Discussion." The International Journal of Interdisciplinary Social Sciences: Annual Review. 
Lowenthal, D. 1998. The Heritage Crusade and the Spoils of History. Cambridge: Cambridge University Press.

Macdonald, S. 2006. "Undesirable Heritage: Fascist Material Culture and Historical Consciousness in Nuremberg." International Journal of Heritage Studies 12 (1): 9-28.

Macdonald, S. 2013. Memorylands: Heritage and Identity in Europe Today. New York: Routledge.

Malpas, J. 2008. "New Media, Cultural Heritage and the Sense of Place: Mapping the Conceptual Ground.” International Journal of Heritage Studies 14 (3): 197-209.

Miles, M. B. and A. M. Huberman. 1994. Qualitative Data Analysis: An Expanded Sourcebook. Thousand Oaks: Sage

Mitchell, T. 2001. "Making the Nation: The Politics of Heritage in Egypt." In Consuming Tradition, Manufacturing Heritage. Global Norms and Urban Form in the Age of Tourism, edited by N. AlSayyad, 212-239. London: Routledge.

Munjeri, D. 2004. "Tangible and Intangible Heritage: From Difference to Convergence." Museum International 56 (1-2): 12-20.

Näss, H. E. 2010. "The Ambiguities of Intercultural Dialogue: Critical Perspectives on the European Union's New Agenda for Culture." Journal of Intercultural Communication 23. http://www.immi.se/intercultural/

Nic Craith, M. 2012. Europe’s (Un)common Heritage(s). Traditiones 41 (2): 11-28.

O'Callaghan, C. 2011. "Urban Anxieties and Creative Tensions in the European Capital of Culture 2005: 'It Couldn't Just Be about Cork, Like'.” International Journal of Cultural Policy 18 (2): 185-204. 
Patel, K. K. 2013. "Introduction.” In The Cultural Politics of Europe. European Capitals of Culture and European Union Since the 1980s, edited by K. K. Patel, 1-15. London: Routledge.

Peckham, R. S. 2003. "The Politics of Heritage and Public Culture.” In Rethinking Heritage. Cultures and Politics in Europe, edited by R. S. Peckham, 1-13. London: I.B.Tauris.

Pocock, C., D. Collett, and L. Baulch. 2015. Assessing Stories before Sites: Identifying the Tangible from the Intangible.” International Journal of Heritage Studies 21 (10): 962-982.

Risse, T. 2003. "European Identity and the Heritage of national culture." In Rethinking Heritage. Cultures and Politics in Europe, edited by R. S. Peckham, 74-89. London: I.B.Tauris.

Sassatelli, M. 2006. "The Logic of Europeanizing Cultural Policy.” In Transcultural Europe. Cultural Policy in a Changing Europe, edited by U. H. Meinhof ans A. Triandafyllidou, 2442. Basingstoke: Palgrave MacMillian.

Sassatelli, M. 2009. Becoming Europeans. Cultural Identity and Cultural Policies. New York: Palgrave Macmillan.

Shore, C. 1993. "Inventing the 'People's Europe': Critical Approaches to European Community 'Cultural Policy'.” Man 28 (4): 779-800.

Shore, C. 2000. Building Europe. The Cultural Politics of European Integration. London: Routledge.

Silva, L. and P. Mota Santos. 2012. "Ethnographies of Heritage and Power." International Journal of Heritage Studies 18 (5): 437-443.

Smith, L. 2006. Uses of Heritage. London: Routledge.

Smith, L. 2011. "Affect and Registers of Engagement: Navigating Emotional Responses to Dissonant Heritage.” In Representing Enslavement and Abolition in Museums: Ambiguous 
Engagements, edited by L. Smith, G. Cubitt, R. Wilson, K. Fouseki, 260-303. London: Routledge.

Smith, L., G. Cubitt, R. Wilson, and K. Fouseki. eds. 2011. Representing Enslavement and Abolition in Museums: Ambiguous Engagements. London: Routledge.

Smith, L. and N. Akagawa. 2009. "Introduction." In Intangible Heritage, edited by L. Smith and N. Akagawa, 1-10. London, Routledge.

Smith, L. and G. Campbell. 2015. "The Elephant in the Room: Heritage, Affect and Emotion." In A Companion to Heritage Studies, edited by W. Logan, M. Nic Craith, and U. Kockel, 443460. London: Wiley-Balckwell.

Tesch, R. 1990. Qualitative Research: Analysis Types and Software Tools. Bristol: Falmer.

Vecco, M. 2010. "A Definition of Cultural Heritage: From the Tangible to the Intangible." Journal of Cultural Heritage 11 (3): 321-324.

UNESCO. 1972. Convention Concerning the Protection of the World Cultural and Natural Heritage. Paris: UNESCO.

UNESCO. 2003. Convention for the Safeguarding of the Intangible Cultural Heritage. Paris: UNESCO.

Vos, C. 2011. "Negotiating Serbia's Europeanness. On the Formation and Appropriation of European Heritage Policy in Serbia.” History and Anthropology 22 (2): 221-242.

Yeoh, B. and L. Kong. 1997. "The Notion of Place in the Construction of History, Nostalgia and Heritage in Singapore." Singapore Journal of Tropical Geography 17 (1): 52-65. 


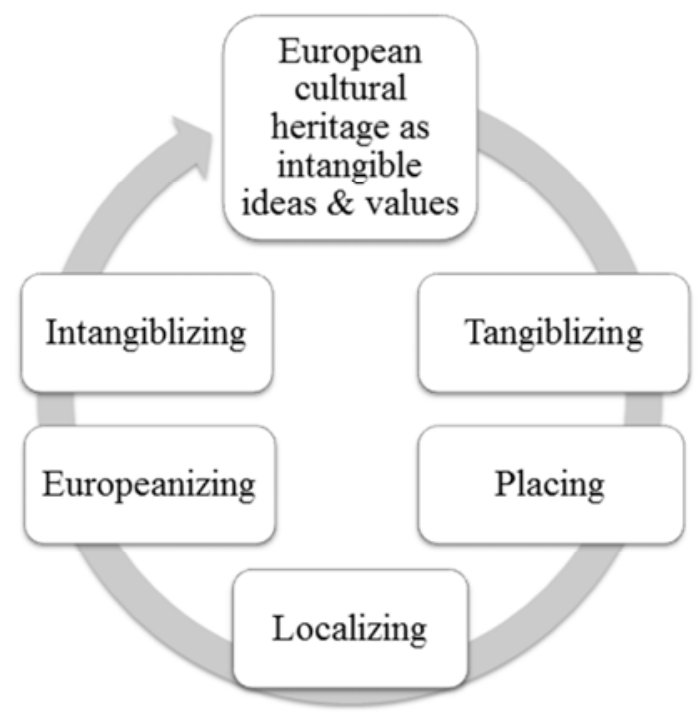

Figure 1. Circulation of the tangibility and intangibility of heritage in EU heritage policy discourse.

\footnotetext{
${ }^{1}$ During the intergovernmental phase of the European Heritage Label, the label was awarded to the historic town of Rousse (Bulgaria), the industrial city of Tomas Bat'a in Zlin (Czech Republic), the historic center of Riga (Latvia), the town of Kuldiga (Latvia), and the historical center of Kaunas (Lithuania). After the label was turned into an official EU action in 2013, only Kaunas has retained its label. The European district of Strasbourg was labeled in 2016.
} 